\title{
Weak yet strong: the uneven power relations of conservation
}

\author{
Chris SANDBROOK
}

Changing behaviour is a central objective of conservation, whether applied to individuals, groups, organizations, corporations or states. Power, defined by the Oxford English Dictionary as 'the capacity to direct or influence the behaviour of others' is therefore an essential ingredient in conservation. Given its importance, the nature and functioning of power has been widely theorized in the social sciences (Gregory et al., 2009, pp. 575-576). Although there are many ideas about how power works, there is general agreement that it can be both a negative and positive force, and that the ability of one actor to influence the behaviour of another depends on their power relations. This editorial is about the balance of power in conservation, and how this is perceived. Using examples drawn from the pages of Oryx and elsewhere, I identify two widespread but contradictory narratives about the power of conservation, and consider their implications.

Firstly, conservation is weak. According to this narrative, mostly used by conservationists, theirs is a minority cause with few powerful friends, seeking against all odds to achieve transformative societal change that is against the interests of those in control (e.g. Araújo \& Wang, 2015; Raine et al., 2016). For example, in relation to challenges facing the implementation of REDD+, 'The political and economic processes that drive tropical deforestation and degradation frequently involve powerful external bodies and individuals that both state institutions and local people may be unable to withstand' (Clements, 2010, p. 310). This narrative argues that to succeed, conservation must persuade large companies, wealthy individuals and (sometimes corrupt) governments to change their practices, and must do so from a weak position (e.g. Cross, 2016). Even calling for such change may be dangerous: 'Should I risk imprisonment, torture, and premature death in an attempt to resist the dominant paradigm and save the living planet for future generations of humans?' (McPherson, 2011, p. 856). From this perspective, conservation's weakness is compounded by the lowly status of conservation stories and arguments in the media (e.g. Sakurai et al., 2013), public opinion surveys and corporate boardrooms. Much recent conservation practice can be interpreted as a strategic response to the perceived weak position described by this narrative-reframing conservation issues using language and ideas more palatable to those with power (e.g. McNeely, 2015). Given the current

Chris Sandbrook UN Environment World Conservation Monitoring Centre, Cambridge, and Department of Geography, University of Cambridge, Cambridge, UK. E-mail chris.sandbrook@unep-wcmc.org global dominance of neoliberal ideology, this has meant reframing conservation as friendly to capital, through ideas like ecosystem services, natural capital accounting, and biodiversity offsetting (Robinson, 2011; Bull et al., 2013).

Secondly, conservation is strong. According to this narrative, mostly used by social scientists, conservation is a powerful, hegemonic industry that can, and does, trample on the rights of marginalized people to get what it wants (e.g. Büscher et al., 2016). For example, 'There may be instances where it will be possible for conservation policies to disadvantage local people without compromising their own objectives. Rural groups may be too weak to effectively resist and obstruct conservation' (Brockington \& SchmidtSoltau, 2004, p. 140). Supporters of this narrative emphasize that much of the work done by conservation organizations takes place in remote rural areas in the global south where poor, politically weak people live at low densities. It is argued that these people are usually ignored by their governments (few votes), by businesses (few dollars) and by development agencies (fewer poor people than urban slums), whereas, in contrast, conservation organizations in such places have shiny vehicles, well-paid staff, strong backing from government agencies (or they are government agencies), and international connections to wealthy donors and opinion formers such as celebrities (e.g. Duffy, 2010; Dowie, 2011). In some cases, the power of conservation may even extend to having access to the use of military force (Lunstrum, 2014). According to this narrative, conservation exploits its position of superior power to inflict harm on local people and their livelihoods in the interests of a distant elite (Brockington \& Schmidt-Soltau, 2004).

The reality is that both narratives are true, and false. False, because conservation is never quite as weak as is sometimes made out-after all, if the global terrestrial protected area estate was a country, at 19.8 million $\mathrm{km}^{2}$ (UNEP-WCMC \& IUCN, 2016) it would be the largest, pushing 17.1 million $\mathrm{km}^{2}$ Russia into second place-and because even where conservation appears to be strong, there are always weapons of the weak (Scott, 1985) that can be used to fight back (e.g. Mariki et al., 2015). True, in the sense that conservation really is weak and powerful at the same time, because its power is unevenly distributed. This unevenness can be spatial (it is much easier to protect land with low economic value; e.g. Morrison et al., 2009), or across types of conservation activity (it is easier to change people's expressed attitudes towards conservation than it is to change their behaviour; e.g. Waylen et al., 2009). 
The uneven distribution of conservation's relative power matters in at least two ways. Firstly, it creates ambiguity in how we think about the fairness of conservation actions. In a context where conservation is relatively weak, it may seem more legitimate for conservation organizations to use strong advocacy and enforcement tactics than in cases where it is relatively strong. For example, I feel reasonably comfortable to hear of the arrest of 'a Chinese national believed to have been coordinating rhinoceros horn smuggling from Namibia' as part of a crackdown on illegal ivory trade in China (Jiang et al., 2016, p. 17), but much less comfortable with a call for "legislation aligned with well-structured mechanisms for surveillance and de facto punishment' to tackle wildlife crime in Brazil (da Silva \& Bernard, 2016, p. 468). The conservation arguments and approach in both cases may be the same, but my judgement of the legitimacy of the actions is affected by my assumptions about the relative power of those involved and the alternatives available to them.

Secondly, many conservation organizations work across multiple contexts and therefore have to cope with being strong and weak at the same time in different areas of their work. This could create the risk that organizations seek out places where they hold relatively greater power, to do things they wouldn't get away with elsewhere. Political ecologists have argued that many conservation actions can be explained this way-from colonial preservationists seeking new estates in Africa because they were losing them at home, to modern international NGOs finding the places where they can get the most bang for their buck (e.g. Neumann, 1998). Addressing this problem requires good internal processes and safeguards to ensure that rules about appropriate actions apply wherever an organization works, and not just where there are regulators to hold conservation to account (Brockington \& Schmidt-Soltau, 2004).

The uneven power relations of conservation are not going to go away, and are not amenable to simple intervention. But it is important for conservationists to reflect on this unevenness and the two narratives of conservation power that it generates. For example, those who find themselves aligned to the weak narrative might take heart from recent celebrations of success in conservation (Balmford, 2017) and think about what they could achieve in their own work through a more confident assertion of conservation's power (including the power of its arguments; e.g. Crane, 2015). On the other hand, those lucky enough to have the power to achieve their conservation objectives, even against the will of others, could benefit from some self-reflection about the responsibility that comes with it. Uneven power doesn't have to lead to uneven behaviour: we need to ensure that conservation actions are fair and balanced wherever they take place.

\section{Acknowledgements}

I thank Bill Adams and Martin Fisher for their critiques.

\section{References}

Araújo, C.C. \& Wang, J.Y. (2015) The dammed river dolphins of Brazil: impacts and conservation. Oryx, 49, 17-24.

BAlmford, A. (2017) On positive shifting baselines and the importance of optimism. Oryx, 51, 191-192.

Brockington, D. \& Schmidt-Soltau, K. (2004) The social and environmental impacts of wilderness and development. Oryx, 38 , 140-142.

Bull, J.W., Suttle, K.B., Gordon, A., Singh, N.J. \& Milner-Gulland, E.J. (2013) Biodiversity offsets in theory and practice. Oryx, 47, 369-380.

Büscher, B., Fletcher, R., Brockington, D., Sandbrook, C., Adams, W.M., Campbell, L. et al. (2016) Half-Earth or Whole Earth? Radical ideas for conservation, and their implications. Oryx, 51, XXX-XXX

Clements, T. (2010) Reduced Expectations: the political and institutional challenges of REDD+. Oryx, 44, 309-310.

Crane, P. (2015) Can we save the charismatic megaflora? Oryx, 49, $377-378$.

Cross, H. (2016) Displacement, disempowerment and corruption: challenges at the interface of fisheries, management and conservation in the Bijagós Archipelago, Guinea-Bissau. Oryx, 50, 693-701.

Da Silva, E.M. \& Bernard, E. (2016) Inefficiency in the fight against wildlife crime in Brazil. Oryx, 50, 468-473.

Dowie, M. (2011) Conservation Refugees: The Hundred-Year Conflict Between Global Conservation and Native Peoples. MIT Press, Cambridge, USA.

Duffy, R. (2010) Nature Crime: How We're getting Conservation Wrong. Yale University Press, New Haven, USA.

Gregory, D., Johnston, R., Pratt, G., Watts, M. \& Whatmore, S. (2009) The Dictionary of Human Geography. 5th edition. Wiley-Blackwell, Oxford, UK.

Jiang, Z., Meng, Z., Zeng, Y. \& Ping, X. (2016) Recent advances in combating illegal ivory trade in China. Oryx, 50, 16-17.

Lunstrum, E. (2014) Green militarization: anti-poaching efforts and the spatial contours of Kruger National Park. Annals of the Association of American Geographers, 104, 816-832.

Mariki, S.B., Svarstad, H. \& Benjaminsen, T.A. (2015) Elephants over the cliff: explaining wildlife killings in Tanzania. Land Use Policy, 44, 19-30.

McNeely, J.A. (2015) A political future for protected areas. Oryx, 49, 189-190.

McPherson, G. (2011) Going back to the land in the age of entitlement. Conservation Biology, 25, 855-857.

Morrison, J., Loucks, C., Long, B. \& Wikramanayake, E. (2009) Landscape-scale spatial planning at WWF: a variety of approaches. Oryx, 43, 499-507.

Neumann, R. (1998) Imposing Wilderness: Struggles Over Livelihood and Nature Preservation in Africa. University of California Press, Oakland, USA.

RAINE, A.F., GAUCI, M. \& BARBARA, N. (2016) Illegal bird hunting in the Maltese Islands: an international perspective. Oryx, 50, 597-605.

Robinson, J.G. (2011) Corporate greening: is it significant for biodiversity conservation? Oryx, 45, 309-310.

Sakurai, R., Jacobson, S.K. \& Carlton, J.S. (2013) Media coverage of management of the black bear Ursus thibetanus in Japan. Oryx, $47,519-525$.

ScotT, J.C. (1985) Weapons of the Weak: Everyday Forms of Peasant Resistance. Yale University Press, New Haven, USA.

UNEP-WCMC \& IUCN (2016) Protected Planet Report 2016. UNEP-WCMC and IUCN, Cambridge, UK \& Gland, Switzerland. Waylen, K.A., McGowan, P.J.K. \& Milner-Gulland, E.J. (2009) Ecotourism positively affects awareness and attitudes but not conservation behaviours: a case study at Grande Riviere, Trinidad. Oryx, 43, 343-351. 